\title{
AUTHOR'S PREFACE TO THE PAPERBACK EDITION
}

IT Has not been long since that the primitiveness of the illiterate, of the man of little learning, of the uncivilized man, was given a new positive value in art, first by Gauguin, then by Picasso. This greater value can arise only out of the intuition and imagination of an artist in close touch with his immediate surroundings.

Modern "regionalisms" are conspicuous for their spontaneous vigor. In Brazil, European and Europeanizing commandos, fanning out from the big plantation houses, were met by matching creative spontaneities issuing from the slaves' quarters.

In connection with the regionalism emerging in Brazil during the nineteen-twenties, it might be mentioned that the much traveled Blaise Centrars was then in São Paulo, that exalted propaganda center for the Semana de Arte, where he was courted by its champions. But after careful examination of the movement, he, so to speak, transferred his interest and intellectual esteem from the absolute Brazilian modernists and their impatience for introducing European novelties into our land, to the regionalists of the Pernambuco capital, although these latter were traditionalists and, only in their own special way, modernists. As a result, Cendrars, impressed by the originality of the book Casa-Grande e Senzala [The Masters and the Slaves], especially in its Dionysiac aspects, singled it out as a new way of writing a human history, through emphases on everyday occurrences and regional peculiarities among common folk, among illiterates, among slaves, in their daily life, sex, cookery, and a Christian religion that was more Dionysiac than Apollonian.

Concerning the traditionalist regionalism that began to appear during the twenties, one should emphasize that it anticipated in the Occident the actual emergence, in various parts of the world, of regionalisms and traditionalisms, or of their resurgence. It signalized a Brazilian tendency toward psychosociocultural pioneering. It was also significant for an outpouring of Brazilian works that were something between scientific and literary; although innovative and even revolutionary under various of their cultural aspects, still they served to give a positive value, in their presentation of Brazil's development, to singularities of manner characteristic of relations between masters 


\section{lxxiv Author's Preface to the Paperback Edition}

of the Big Houses and slaves from the senzalas. This relationship imparted to the Big Houses religious, culinary, and sexual spontaneities arising out of the slaves' quarters.

The recognition of mixed values arising from the slaves' quarters and assimilated by the Big Houses has resulted in the bringing to light of hidden values and the rejection of evaluations based on the application of imperialist European criteria, according to which the casasgrandes represented an absolute superiority over the senzalas. The conditioning of Brazil's sociocultural future upon its ecology, in large part tropical, may be said to have favored the senzalas. The mixture of races, accompanied by a fecund interpenetration of cultures-European, Amerindian, Afro-Negro-pointed up the advantages of the Big-House-and-slave-quarters complex. Although this situation was considered by French Le Bons and Argentine Ingenieroses as totally negative, their judgments were reduced to insignificance both by in-depth scientific sociological reexamination and by conclusions concurring with that reexamination, independently arrived at by competent foreign observers, men of the stature of the two French Bastides, Arbousse and Roger, and Jean Duvignaud, the German Konrad Guenther, the Italian Roberto Rossellini, the Englishmen Aldous Huxley, Asa Briggs, and Arnold Toynbee. In the end the Le Bons and Ingenieroses served only to confer prestige upon the miscegenetic action of the process represented by the interpenetration of opposites as found in Brazil.

The above conclusions were anticipated in books of applied social science, among them the pioneering Casa-Grande e Senzala, a work by a Brazilian author whose education in foreign universities had been completed by his telluric origin as a native of the tropics of his own country. His opinions also appeared in serious studies from a Brazilian perspective of social and anthropologically social concepts, such as his Problemas Brasileiros de Antropologia [Brazilian Problems in Antbropology] and Sociologia, Introdução ao Estudo dos seus Princípios [Sociology: An Introduction to the Study of Its Principles], but above all in that book of pioneering par excellence, Casa-Grande e Senzala.

When one says of the Portuguese member of the trans-European expansion that he showed himself to be more Christiano-centric than ethnocentric, there is no intention of investing him with virtues or praiseworthy religious attributes and thus recognize in him a departure from ethnocentrically imperialist tendencies, that is, tendencies among certain trans-Europeans to consider themselves ethnocentric and, as such, ethnically and culturally superior to non-Europeans. 


\section{Author's Preface to the Paperback Edition lxxv}

Perhaps he felt that he was more likely to be recognized as a member of a prestigious group if he called himself Christian rather than Portuguese, because as a Portuguese he felt less secure than other Europeans of both his ethnic and cultural superiority. By giving himself the title "Christian" he would compensate for that insecurity. According to the chroniclers, it used to be said that such a Portuguese man spoke, not Portuguese, but Christian. He was, it seems, a European who perceived that his national language lacked recognition for cultural values present in other national languages of the trans-European expansions beginning in the sixteenth century, such as Spanish, French, and English. Thus, wrapping himself in the prestige of the title "Christian" by giving that designation to his style of speech, he would be defining himself as Christiano-centric rather than ethnocentric. This definition of expressing himself in Christian speech distinguished him and served to confer dignity upon a conduct that was more given to miscegenation than that of other Europeans in the trans-European expansion. It was as if the accident of speech accentuated his disparagement of his biocultural group and its identification with the practice of biological confraternization with colored people. His attitude was political, but it also had something about it at once ethically and mythically Christian.

It must be remembered that from remote times Portuguese kings and their bishops had begun to entrust to miscegenates of Amerindian or Afro-Negro blood important posts in the colonial administration and in the Catholic hierarchy. Such men received titles of nobility like the Dom bestowed upon the Amerindian Brazilian Felipe Camarão for his bravery during the expulsion of the Dutch from Brazil, and they held posts of honor, not only religious but also political, like the one conferred upon the not entirely Aryan Antônio Vieira in the seventeenth century.

The Big-House-and-slave-quarters complex represents a symbiosis, with the slave influencing the master within a patriarchal familial system, the Catholic church being annexed after a fashion to that complex. And the complex was an expression of private initiative, something that caused the Portuguese colonization of Brazil to more nearly resemble the English colonization of what was to become the United States of North America than the colonization of Spanish America conducted by the royal metropolitan power and by theocratic power.

The familial complex, of which the Big House in conjunction with the slaves' quarters was the expression, included, in its socioeconomic 


\section{lxxvi Author's Preface to the Paperback Edition}

power, accretions to its basic role as residence of the patriarchal family-accretions in the form of a church, a bank, a school, and centers not only for spiritual assistance but also for social welfare, not only for slaves but also for small farmers and for dependents, the latter being a species of poor relations attached to the Big Houses as, so to speak, sociological members of the principal family. This system grew out of the most patriarchal institution imaginable, in a Brazil with a patriarchal society based on slavery. The institution was the compadrio, a shared paternity, an intimacy between godparents and natural parents. With the blessing of the Catholic church, the owners of a typical Big House were, by dint of noblesse oblige, godfather and godmother to the children of small farmers, to the children of dependents, and, above all, to the slaves' offspring, some of whom took the patriarch's family name. To be a compadre of these patriarchs, that is, to have them as godparents to one's child, was more than an honor; it meant the acquiring of rights to patriarchal protection. To be their godchild was to grow up with special rights to such protection.

For these reasons, not a few sons of slave mothers or fathers. or sons of dependents living in the Big Houses, received, when sufficiently intelligent, the same education as the young masters of the house. They too were taught by the family priest, were sent to study in schools of higher learning, and were favored in their advancement as professionals by government administrations attentive to requests by influential patriarchs. All this was an extension of the patriarchal family's power over the psychosociocultural whole.

Thus are explained the accounts of godsons of Afro-Negro origin, sons of slave mothers or fathers who, with patriarchal support for their superior intelligence, graduated with degrees from institutions of higher learning. Among these accounts we may single out the remarkable example of Teodoro Sampaio, who, though born of a slave mother, attained an eminent position and profound influence in the society and culture of nineteenth-century Brazil. Nor did he fail to achieve recognition for his superior intelligence; a civil engineer, he was a graduate of Rio de Janeiro's Polytechnic School-a difficult course-and filled important posts in both the professional and public life of Brazil. Hence it may be concluded that the Big-House-slavequarters-chapel system or complex favored, in its own special way, the utilization of the supremely gifted sons of slaves for the improvement of Brazilian culture and the democratization of Brazilian society, 


\section{Autbor's Preface to the Paperback Edition lxxvii}

and not only the sons of slaves but also the sons of tenants and small farmers.

It is interesting that the dramatist Eugene Ionesco, famous for his quick wit, noticed the sociologically Christiano-centric spirit present in not a few expressions of Brazilian social development. He got this idea from reading the book Casa-Grande e Senzala and discussing it with its author. One of Ionesco's observations was that almost the same thing that had already taken place in such countries of Europe as Rumania and Hungary had been repeated in Brazil. For the Latin Rumanian, though not for the Slavic Rumanian like himself, Christianization, he felt, must have restrained ethnocentric cultural excesses, which in the absence of a Christian culturally comprehensive Europeanness would have tended to be nationalistic.

In the Brazilian, Christianization gave rise to a super-European consciousness that was above political state nationalism and found its most effective instrument for symbiotic action in the reciprocity functioning within the Big-House-and-slave-quarters complex.

It may perhaps be said that not a few of the eyes today reading $T$ The Masters and the Slaves are mouths rather than eyes-mouths repeating the words read with the sensuous enjoyment of one who repeats them for the pleasure of tasting them, savoring them, almost masticating them at times without bothering to completely understand their exact scientific meaning.

The Masters and the Slaves is a book in which the author's scientific learning performs the role of servant to his intuition or his musically verbal art rather than to a display of merely scientific knowledge. The author has read Spencer, read Comte, studied Darwin and evolution. $\mathrm{He}$ was a pupil of Boas and Giddings at Columbia University, of Lucien Febvre in Paris. But he arrived at a point where, like one who plays music by ear, his scientific idiom was blended with the language of a metascience in large part intuitive and existential.

Some such thing may have occurred to a certain extent with Euclydes da Cunha. In The Masters and the Slaves, however, it was through a kind of musical equivalent that was more Wagnerian than classical, consisting of sounds at times discordant rather than quite harmonically correct. Its literary music may perhaps be said to be a distant relative, so to speak, of Stravinsky's, with a soupçon of VillaLobos.

For these reasons, the author has felt obliged to emphasize once again the standard by which he sought, some years ago, to develop 


\section{lxxviii Author's Preface to the Paperback Edition}

his plan for reconstructing and interpreting the Brazilian patriarchal society or tutelary family. It was his intention to study, in its different types and styles of habitation, the reflections of diverse types and styles of life and culture as well as expressions and conditions of the living together as a family and the resultant interpenetration and synthesization of values. Although synthesization and interpenetration did take place under the patriarchal system or organization, it was at the cost of its purity and finally of its integrity.

Within this system there was close communication-not merely separation or differentiation-between the Big House and slave quarters, and only later between the mansions and the shanties of the cities. There was synthesis, not just antithesis; affective complement, not merely the antagonism of economic diversification. In no other way can one explain the growing importance among us of hybrid manifestations not only of culture but also of physical types. The original system scarcely appears above the ocean of crossbreeding that overwhelms it, and within which absolutely pure values of one origin or another-European or Amerindian, Lusitanian or African, civilized or primitive, seignorial or servile-survive only in the form of tiny islands every day more insignificant, ethnographic, ethnic, or aesthetic curiosities rather than sociological realities. They are floating fragments broken away from a disintegrating continent or archipelago rather than terra firma capable of resisting, even in a reduced form, the triumphant flood. Out of this sea is emerging a new superficies, a new configuration of culture, new forms of society characterized principally by human beings of different sex, origin, age, and profession, living together as a family that merits the qualifier "democratic." It is a society characterized by an inceptive generalization in type of man and in type of house. The type is not unique, however, for it retains certain individual characteristics of race and class, but it is much less differentiated than formerly by extremes of social position or situation in the social space.

In the Brazilian cities of today one rarely finds stately houses tenanted only by wealthy individuals or patriarchal families. Instead there are many collective habitations, as already mentioned: hotels, boardinghouses, hospitals and private sanatoriums, asylums, military headquarters, private schools, apartment buildings, and workmen's cooperative lodgings. There are a great many average single houses, neither very large nor extremely small for the physicosocial space they occupy: a middle term between the former town house replete with rooms of large and small dimension and the one- and two-room 


\section{Autbor's Preface to the Paperback Edition lxxix}

shacks that are still abundant in the cities and in the country-abundant and overflowing with occupants. The most noticeable change in the Brazilian landscape is the decrease in city mansions, big plantation houses, and ancestral estates occupied by individuals or by patriarchal families.

This alteration in architectonic volume and in the space occupied by it marks the final disintegration of the patriarchy in our society and in our society as reorganized on a new basis, although this new society is still impregnated with patriarchal survivals. This aspect of Brazilian social development is taken up in a subsequent essay, Order and Progress, dedicated mainly to the analysis of our transition from slave labor to free labor. That transition coincided with the abandonment of the monarchical form of government for the republican, on behalf of which Brazilians of São Paulo and other states, and principally the positivists of Maranhão, Rio de Janeiro, and Rio Grande do Sul, had begun to work actively as far back as $\mathrm{I} 870$.

These republicans, some of them masters of casas-grandes, were Brazilians of a most progressive type, but the majority of them would have rejected a republic that was incapable of assuring the nation the order necessary for material development of the cities and for mechanization of industry and farming, forms of progress they ardently desired for Brazil. Hence, the positivist motto adopted by the republic, founded in 1889 , would have answered the aspirations of these republicans of ours, even ones ideologically far removed from Comte's philosophy and its adherents. It is not without significance that, after the founding of the republic, various of its principal leaders-some of mixed race but with aristocratic blood, some of plebeian origin who had been made aristocratic by means of academic instruction or by reason of marriage with the young daughter from a Big House or with a town house girl-should have distinguished themselves as particularly energetic chieftains in defense of Order. Order was now middle class but still patriarchal and constituted the security of the Brazilian society of those days. One of these leaders, handsome and powerful, the very picture of a highborn Moor, confronted with unusual force a crowd in Rio de Janeiro which was the perfect picture of the capoeira, a mass expression of the free Negro's hatred and the poor, free mulatto's hatred for the rich white man, the native's hatred for the European, the shanty crowd's hatred for those who dwelt in fine city houses. That knife-wielding riffraff had distinguished themselves by their defense of the throne under the name "Black Guard" during the days when the monarchy found itself re- 


\section{lxxx Author's Preface to the Paperback Edition}

jected and spurned by so many illustrious gentlemen of Big House and city mansion, of general headquarters and bishop's palacegentlemen disappointed, some with the emperor's abolitionist excesses, others with his exaggerated patrician or royalist ways. It was then that the monarchy, in the person of Isabel, was acclaimed "savior" and found sympathy and even dedication among stalwart cabras of mingled African, Indian, and white blood, Negroes, and scapegrace young mulattoes from the city shanties. Many of these were runaway slaves or descendants of runaway slaves and, though despairing of their relations as "sons" with "fathers" on plantations or in other patriarchal establishments, they still felt the need of "fathers" or symbolic "mothers" or ideals that would protect them, if not actually in the manner of their neglectful or mean fathers, at least in a mystical or symbolic manner.

In this regard, it only remains to add the following footnote: Just as there has been an increase in medium-size one-story houses, habitations of a middle class into which many an old wealthy casa-grande family had been fragmented and there joined by many a mulatto and free Negro who had elevated himself through mechanical skills, in like manner the city mansion, after succeeding the big plantation house as the expression of the patriarchal system's domination of the Brazilian landscape, with the decline or weakening of that domination, experienced the degeneration of its former stately residences into collective habitations-slum tenements, brothels, boardinghouses, hotels, asylums, and the like-or their transformation, with complete loss of character, into government ministries, embassies, consulates, clubs, newspaper offices, private sanatoriums, Masonic lodges, theaters, stores, and so on.

Corresponding to the decline of the wealthy individual's political power with its seat in a Big House of the most aristocratic, most prestigious, or most markedly patriarchal character, was the increasing public political power lodged in judicial, police, military, or simply bureaucratic agencies of the monarchic government and, later, of the republican. Not infrequently these agencies were installed in former patriarchal residences as though in the ruins of forts captured from a powerful enemy; even in their conquered state these made-over ruins were conspicuous for the survival or the look of their former power. For example, the Catete Palace and the Itamarati Palace, in Rio de Janeiro, even today recall to the eyes of Brazilian and foreigner alike the patrician elegance of patriarchal Brazil; so opulent was it, especially in the Rio de Janeiro area, that the statesmen of the republic 


\section{Author's Preface to the Paperback Edition lxxxi}

of 1889 found in the residences of former barons of the empire better palaces in which to install the principal organs of the republican government than in the very residences of the former emperors and princes. The patriarchal casa-grande in the two signal instances cited above impressed the conquering heroes of ' 89 by the solidity of its architectonic nobility. This nobility, adapted to the land and the milieu, threw into contrast the badly proportioned, uncouth architecture of edifices specially built by the republican governments to house state offices.

The same may be said of the edifices erected by the last governments of the monarchy; their dignity does not equal that of the private mansions built by barons still of the patriarchal class, a sign that the Brazilian patriarchal system succeeded in expressing itself in types of private residence which surpassed the architecture of officialdom in authenticity, in ecological qualities of adaptation to the milieu and domination of the landscape, and even in nobility of construction and style. Such buildings demonstrate that the patriarchal system in more than one aspect created values that were characteristically Brazilian as well as characteristically patriarchal, or "tutelary," as Professor Zimmermann would say. He rejected the expression "patriarchal" because it seemed to attribute absolute power to the individual patriarch, whereas that power resided with the family, involved as it was in tutelary functions, rather than with its head. Patriarchal or tutelary, it is certain that the Brazilian family with its centers of authority in big plantation houses and city mansions created among us an architecture representative or characteristic of its power.

It follows, then, that not all enthusiasts of the old-time architecture of patriarchal, or tutelary, residences are simple or perverse amateurs of the archaic, clinging with the fond love of the antiquarian to relics of a social system that expressed itself in those houses, which were at times ugly but by the same token sturdy, like the Portuguese mothers within. And there are qualities in those houses, as in the women, which often compensate for their lack of physical beauty with, for example, a hospitable gentleness, an honesty, or a dignity tempered by simplicity.

It is plain that, once the old system expired, its type of residence should not be capriciously or arbitrarily perpetuated in a society that was becoming collectivist on the one hand and, on the other, individualist in opposition to the private nature of the economic system or of the patriarchal organization, which was at once individualist and communist, given the absorption of the individual in the family and 


\section{lxxxii Autbor's Preface to the Paperback Edition}

the subordination of the state to the nobleman. Nonetheless one must not fail to recognize in the Brazilian patriarchal casa-grande a source of valuable suggestions for the architect who wishes to create for Brazil collectivist architecture that will also be individualized and, at the same time, in conformity with the teaching of the Brazilian experience; it should not be inspired by political passion or aesthetic partisanship, which are regularly in conflict with that experience, nor should it be created in a vacuum.

In Brazil, what found its expression in types of residence, which harmonized with the land and the milieu, like the Big House or even the slave's shanty, was not only an economic system or a familial or cultural system; it was also the human being. It was the Brazilian, the man of various origins, who had to conquer the hostility of the tropics to those higher forms of Christian and Mussulman civilization brought from Portugal to the American colony, not only by Europeans but also, to a much lesser degree, by Africans. These higher forms of civilization, it is true, here turned soft or corrupt. But it is extraordinary how many of them got spread, though in a weakened and impure state, over a space physically so extensive and socially so arid as the Brazil of the early days of colonization.

From that dissemination of higher forms of civilization in so vast a tropical land resulted the first great modern civilization in the tropics: the Brazilian. And tremendous as was the work of the missionariesCarmelite, Benedictine, Jesuit, Franciscan-and of agents of the Crown or the government, the truth is, the aforesaid dissemination seems to have been brought about principally by the Big Houses and their chapels, and only to a lesser extent by the regular convents or cathedrals, or by the palaces and other establishments belonging to the king and, after Brazil's independence, to His Majesty the Emperor.

Recife

Gilberto Freyre

1986 